\title{
pH Characterization of Digestive Enzyme and In vitro Digestibility of Red Bee Shrimp Caridina cantonensis (Decapoda: Atyidae)
}

\author{
Supalug Kattakdad ${ }^{1}$, Orapint Jintasataporn*1, Wanchai Worawattanamateekul ${ }^{2}$ and Srinoy Chumkam ${ }^{3}$ \\ ${ }^{1}$ Department of Aquaculture, Faculty of Fisheries, Kasetsart University, Thailand \\ ${ }^{2}$ Department of Fishery Products, Faculty of Fisheries, Kasetsart University, Thailand \\ ${ }^{3}$ Department of Agricultural Technology, Valaya Alongkorn Rajabhat University, Thailand
}

\begin{abstract}
The characteristics of digestive enzyme from red bee shrimp (Caridina Cantonensis), a tiny ornamental shrimp, were investigated under various $\mathrm{pH}$ ranging from 2 to 12 . The aim of this study was to find out the specific activities of protease, amylase, lipase, cellulose, trypsin and chymotrypsin and in vitro raw materials by shrimp enzyme digestibility. Fifteen and sixty-day old shrimp were obtained from private farms in Bangkok, Thailand. Protease, lipase, amylase, cellulase, trypsin and chymotrypsin specific activity were determined. The results showed that protease activity had its optimal activity at $\mathrm{pH}$ ranging from 8 to 10 and showed the highest activity at $\mathrm{pH} 10$ in both age groups. The alkaline amylase activities were found to be significantly higher than acidic amylase in both age groups. Both acidic and alkaline amylase activity of the 15-day old shrimp was significantly lower than the larger shrimp. The Lipase activity in the 60-day old shrimp showed the highest activity at pH 12, $\mathrm{pH} 10$ and 11, respectively. In the 15-day old shrimp, the lipase activity was stable over a broad pH ranging from 2-12. In the 60-day old shrimp the cellulase activity showed the highest activity at assay condition $\mathrm{pH} 7$ and decreased when $\mathrm{pH}$ levels increased. In the 15-day old shrimp, cellulase activity showed optimal $\mathrm{pH}$ at $\mathrm{pH} 8$ and 11 . The trypsin and chymotrypsin activity at neutral to weak alkaline condition was greater under acidic condition in both age groups. The activity of 15-day old shrimp was significantly lower than the older shrimp. Regarding in vitro digestibility, the study on protein digestion showed that fish meal was suitable to be a protein source for red bee shrimp. The carbohydrate digestibility showed that wheat flour and maltodextrin were more appropriate as a carbohydrate source for red bee shrimp than cassava, rice bran and $\mathrm{Na}$-alginate. Therefore, it can be concluded that red bee shrimp had diet digestibility in neutral to mid alkaline condition. The animal protein materials are appropriate to be red bee shrimp feed ingredients with low fiber and carbohydrate source.
\end{abstract}

Keywords: Digestive enzyme; In vitro digestibility; Red bee shrimp; Caridina cantoensis

\section{Introduction}

The small atyid shrimp are widely found in tropical clean freshwater areas, including rivers, streams, lakes, reservoirs, mountain creeks, pools, rice fields and irrigation canals [1-22]. Caridina is a kind of atyid Asian fresh waters shrimp (160 species in Asia and; 83 species in China) . The red bee shrimp is a red mutation of the wild bee shrimp (Caridina cantoensis). It is one of the most popular shrimp for the aquarium trade in Thailand. In spite of topics concerning biology, management and culture this shrimp receives only little attention. [22-39]. About the nutritional requirements in particular, the situation is not much different from other matters. Although many studies on digestive enzymes of aquatic animals have been conducted, there are very few works focusing on the Caridina species. The studies on digestive enzymes of aquatic animals, however, mainly involves freshwater pearl mussel [1], Nile tilapia [3], Penaeus vannamei [10], Penaeus japonicas [13], Asian bony tongue [28], spiny lobster [30], red swamp crayfish [38], pacific crayfish [15] and pacific brown shrimp [37]. Aquatic animal nutrition is necessary for aquaculture as the food component highly depends on knowledge of the nutritional biochemistry and physiology of each species [37]. The knowledge of digestive enzymes of aquatic animals helps in providing an understanding of digestive capabilities, which in turn leads to the ingredient selection for a diet. [37] The objective of this study was to investigate the characteristics of the main digestive enzymes (protease, amylase, lipase, cellulase, trypsin and chymotrypsin) under various $\mathrm{pH}$ conditions of 15 and 60 day old red bee shrimp (C. cantonensis) and to discover in vitro digestibility of the raw materials. It is expected that the knowledge on enzyme activity and raw material digestion of the red bee shrimp will benefit the future development of artificial feed formulation for the shrimp at various stages.

\section{Materials and Methods}

\section{Buffer $\mathrm{pH}$ preparation}

The buffers used in this study for $\mathrm{pH}$ 2-12 were glycine- $\mathrm{HCl}$ buffer for $\mathrm{pH} 2$, citrate phosphate buffer for the $\mathrm{pH}$ range 3-5, phosphate buffer for the $\mathrm{pH}$ range $6-8, \mathrm{NaHCO}_{3}-\mathrm{Na}_{2} \mathrm{CO}_{3}$ buffer for the $\mathrm{pH}$ range 9-10, $\mathrm{Na}_{2} \mathrm{HPO}_{4}-\mathrm{NaOH}$ buffer for the $\mathrm{pH} 11$ and $\mathrm{KCl}-\mathrm{NaOH}$ for the $\mathrm{pH} 12$ (34).

\section{Enzyme study}

Enzyme extraction: Fifteen and sixty-day old red bee shrimp were obtained from a private farm in Bangkok, Thailand. The whole body of the shrimp was homogenized on ice without adding any buffer solution. The homogenate was centrifuged at $12,000 \mathrm{rpm}$ for $15 \mathrm{~min}$ at $4^{\circ} \mathrm{C}$ then the supernatant below lipid layer was collected and kept at $-20^{\circ} \mathrm{C}$ until investigate for protein content [24] and enzyme specific activities of protease, amylase, lipase, cellulose, trypsin, chymotrypsin including raw material digestibility.

*Corresponding author: Orapint Jintasataporn, Department of Aquaculture, Faculty of fisheries, Kasetsart University, Thailand, Tel: +662 579 2924; E-mail: ffisora@ku.ac.th; ffisora@ku.ac.th

Received January 23, 2018; Accepted February 27, 2018; Published March 02 2018

Citation: Kattakdad S, Jintasataporn O, Worawattanamateekul W, Chumkam S (2018) pH Characterization of Digestive Enzyme and In vitro Digestibility of Red Bee Shrimp Caridina cantonensis (Decapoda: Atyidae). J Aquac Res Development 9: 522. doi: 10.4172/2155-9546.1000522

Copyright: ( $) 2018$ Kattakdad S, et al. This is an open-access article distributed under the terms of the Creative Commons Attribution License, which permits unrestricted use, distribution, and reproduction in any medium, provided the original author and source are credited. 
Citation: Kattakdad S, Jintasataporn O, Worawattanamateekul W, Chumkam S (2018) pH Characterization of Digestive Enzyme and In vitro Digestibility of Red Bee Shrimp Caridina cantonensis (Decapoda: Atyidae). J Aquac Res Development 9: 522. doi: 10.4172/2155-9546.1000522

Page 2 of 6

Determination of protease specific activity: The protease activity was determined by using the modified casein method (29). Crude enzyme $20 \mu$ l was incubated with $250 \mu \mathrm{l}$ of $2 \%$ casein substrate dissolved in various $\mathrm{pH}$ buffers $2-12$. The reaction mixture was incubated for 10 minutes at room temperature and then the reaction stopped by adding $1 \mathrm{ml}$ of $1.2 \mathrm{M}$ trichloroacetic acid (TCA). The control (blank) was prepared by mixing the crude enzyme with TCA to denature the enzymes before adding the substrate [1]. The reaction solution was mixed and stood for 15 minutes at room temperature $\left(25^{\circ} \mathrm{C}\right)$ to complete the reaction. TCA was added after that and centrifuged at 10,000 rpm for 5 minutes. The supernatant was transferred to a test tube then 1 $\mathrm{ml}$ of $0.4 \mathrm{~N} \mathrm{NaOH}$ added and incubated at $40^{\circ} \mathrm{C}$ for 10 minutes. After incubation, $200 \mu \mathrm{l}$ of $50 \%$ Folin reagent were added to the solution and then incubated at room temperature for 10 minutes. Total protease activity was measured at absorbance $660 \mathrm{~nm}$. The production of tyrosine was determined by means of Folin-hydroxybenzene. One unit of protease activity ( $\mathrm{U} \mathrm{mg}^{-1}$ protein) was defined as $1 \mathrm{mM}$ of tyrosine liberated by hydrolysing casein in $1 \mathrm{~min}$. The protein concentration of the enzyme extracts was determined by using the Lowry method, using bovine serum albumin as a standard protein.

Determination of amylase specific activity: Amylase specific activity was determined by the increasing of reducing sugar (maltose) from the hydrolysis of $\alpha-D(1,4)$ glycosidic bond in polysaccharides, and stained with 3,5-dinitrosalicylic acid (DNS) (1). Total amylase activity was determined by using the Bernfeld method (2). Starch was used as the substrate by boiling $1 \%$ soluble starch for $10 \mathrm{~min}$ in the various buffers pH 2-12 and $60 \mu \mathrm{l}$ of $6 \mathrm{mM} \mathrm{NaCl}$. Crude enzyme extract $20 \mu \mathrm{l}$ was added to $250 \mu \mathrm{l}$ of substrate, and then incubated at room temperature $\left(25^{\circ} \mathrm{C}\right)$ for 5 minutes. The reaction was stopped by $250 \mu \mathrm{l}$ of $1 \%$ DNS after that heated in a boiling water bath for 5 minutes then cooled down and $1.5 \mathrm{ml}$ of distilled water added. The control (blank) was prepared by adding DNS reagent before the crude enzyme. Amylase activity was measured the absorbance at wavelength $550 \mathrm{~nm}$ with a spectrophotometer. One unit of amylase activity $\left(\mathrm{U} \mathrm{mg}^{-1}\right.$ protein) was defined as $1 \mathrm{mM}$ of glucose per min per $\mathrm{mg}$ protein.

Determination of lipase specific activity: Lipase specific activity was measured according to Markweg et al. (25). p - nitrophenylpalmitate (pNPP) was used as the substrate. Crude enzyme extract $20 \mu \mathrm{l}$ was added to $100 \mu \mathrm{l}$ of $0.1 \mathrm{M} \mathrm{p}$ - nitrophenylpalmitate (pNPP) substrate and 880 $\mu \mathrm{l}$ of the various $\mathrm{pH}$ buffers $2-12$ then incubated at room temperature $\left(25^{\circ} \mathrm{C}\right)$ for 30 minutes and the reaction stopped by adding $400 \mu \mathrm{l}$ of $0.1 \mathrm{M} \mathrm{Na}_{2} \mathrm{CO}_{3}$ after that centrifuged at $4000 \mathrm{rpm}$ for 10 minutes. The supernatant was collected then measured at absorbance $420 \mathrm{~nm}$ by spectrophotometer. The control (blank) was prepared by mixing the crude enzyme with $\mathrm{Na}_{2} \mathrm{CO}_{3}$ to denature the enzymes before adding the substrate. One unit of lipase activity ( $\mathrm{U} \mathrm{mg}^{-1}$ protein) was defined as 1 $\mathrm{mM}$ of p-nitro phenol per min per mg protein.

Determination of cellulase specific activity: Cellulase specific activity was measured in accordance to Miller (26). Carboxyl methyl cellulose (CMC) was used as the substrate and prepared by weighted $1 \%$ of CMC with buffer $\mathrm{pH} 2-12$. The crude enzyme extracted, $20 \mu \mathrm{l}$, was added to $250 \mu \mathrm{l}$ of $1 \% \mathrm{CMC}$ then incubated at room temperature $\left(25^{\circ} \mathrm{C}\right)$ for 15 minutes. The reaction was stopped by using $250 \mu \mathrm{l}$ of $1 \%$ DNS and heated in water bath at $100^{\circ} \mathrm{C}$ for 5 minutes, after that cooled down and $1.5 \mathrm{ml}$ of distilled water added. The control (blank) was prepared by adding DNS reagent before the crude enzyme. The absorbance was measured at wavelength $540 \mathrm{~nm}$ with a spectrophotometer. One unit of cellulase activity ( $\mathrm{U} \mathrm{mg}^{-1}$ protein) was defined as $1 \mathrm{mM}$ of maltose per min per mg protein.
Determination of trypsin specific activity: Trypsin specific activity of crud enzyme extract was determined by using the method of Sunde et al. (33) and modified from Torrissen et al. [35]. The reaction mixture containing $1,000 \mu \mathrm{l}$ of trypsin substrate $(1.25 \mathrm{mM}$ benzoylL-arginine- $p$-nitroanilide in $5 \%$ dimethylformamide and made up to solution with buffer $\mathrm{pH}$ ) were mixed with $5 \mu \mathrm{l}$ crude enzyme extract. Trypsin activity was determined by measuring the rate of $p$-nitroaniline production during the first $0-15 \mathrm{~s}$ of the reaction at absorbance 410 $\mathrm{nm}$. The control (blank) was prepared by adding trypsin substrate 1000 $\mu \mathrm{l}$ without adding crude enzyme. One unit of trypsin activity ( $\mathrm{U} \mathrm{mg}^{-1}$ protein) was defined as $1 \mathrm{mM}$ of p-nitroaniline per min per $\mathrm{mg}$ protein.

Determination of chymotrypsin specific activity: Chymotrypsin specific activity was measured using a similar method as trypsin specific activity, determined in a reaction mixture containing $1,000 \mu \mathrm{l}$ of substrate $(0.1 \mathrm{mM} \mathrm{N}$-succinyl-Ala-Ala-Pro-Phe-p-nitroanilide in $5 \%$ dimethylformamide and the solution made up with buffer $\mathrm{pH}$ ), then 5 $\mu \mathrm{l}$ of crude enzyme extract was added. Chymotrypsin specific activity was determined by measuring the rate of $p$-nitroaniline production during the first $0-15 \mathrm{~s}$ of the reaction at absorbance $410 \mathrm{~nm}$. The control (blank) was prepared by adding trypsin substrate $1,000 \mu \mathrm{l}$ without adding the crude enzyme. One unit of chymotrypsin activity ( $\mathrm{U} \mathrm{mg}^{-1}$ protein) was defined as $1 \mathrm{mM}$ of p-nitroaniline per min per $\mathrm{mg}$ protein.

\section{In vitro digestibility}

Sample preparation: In vitro digestibility of raw material was investigated by using an enzyme extract from the whole body of 15 ( $0.489 \mathrm{mg}$ Protein) and 60 (0.8794 mg Protein) day old red bee shrimp according to the method modify from Rungruangsak-Torrissen et al. [32]. In vitro digestibility of feed materials was performed with approximately $30 \mathrm{mg}$ of each sample, adding $30 \mathrm{ml}$ of buffer $\mathrm{pH} 8$ and mixed thoroughly. The mixtures were incubated for $24 \mathrm{~h}$. at $25^{\circ} \mathrm{C}$ and the samples were run in triplicate. Before performing digestion analysis, $1.5 \mathrm{ml}$ of each mixture was collected as the control, immediately heated at $100^{\circ} \mathrm{C}$ for $5 \mathrm{~min}$ to inactivate the enzyme, and frozen at $-80^{\circ} \mathrm{C}$ for later determination. The fish meal, soy bean meal, fermented soy bean, squid meal, shrimp meal, spirulina, rice bran, cassava, wheat flour, $\mathrm{Na}-$ alginate and maltodextrin were determined on protein digestibility and carbohydrate digestibility.

Determination of protein digestibility: The protein digestibility was determined by measuring the reactive amino group by using Ninhydrin assay [27]. A solution $1.0 \mathrm{ml}$ of undigested control (0h) or the digested mixture $(24 \mathrm{~h})$ was mixed thoroughly with $1.0 \mathrm{ml}$ of cdninhydrin reagent. The mixture was incubated at $84^{\circ} \mathrm{C}$ for 5 minutes and suddenly cools down on ice. The supernatant was measured at 507 $\mathrm{nm}$ and the concentration of the reaction amino group was calculated using Tyrosine as the standard. The in vitro digestibility of protein was expressed as $\mathrm{mg}$ Tyrosine/mg sample.

Determination of carbohydrate digestibility: The carbohydrate digestibility was determined by measuring the increase of reducing sugar by using DNS assay. A solution of $250 \mu \mathrm{l}$ of digested mixture and $250 \mu \mathrm{l}$ of dinitrosalicylic acid (DNS) were heated in boiling water for $5 \mathrm{~min}$ and cool down to room temperature. The absorbance was measured at $540 \mathrm{~nm}$ and then compare with the maltose standard curve. The in vitro digestibility of carbohydrate was expressed as $\mathrm{mg}$ maltose/mg sample.

\section{Statistical analysis}

Mean and standard deviation of each enzyme specific activity were calculated. Statistical analysis at $95 \%$ significant level was determined 
Citation: Kattakdad S, Jintasataporn O, Worawattanamateekul W, Chumkam S (2018) pH Characterization of Digestive Enzyme and In vitro Digestibility of Red Bee Shrimp Caridina cantonensis (Decapoda: Atyidae). J Aquac Res Development 9: 522. doi: 10.4172/2155-9546.1000522

Page 3 of 6

using analysis of variance (ANOVA), and multiple comparisons were analysed by using the Duncan Multiple Range Test.

\section{Results}

\section{Enzyme assay}

All the enzyme specific activity assays showed significant differences related to the different age and $\mathrm{pH}$ condition (Figures 1 and 2). According to the results, the protease activity of red bee shrimp showed its optimal activity at a $\mathrm{pH}$ ranging from 8 to 10 and showed the highest activity at $\mathrm{pH} 10$ assay condition in both age groups. When compared the protease specific activity of both age groups it was found that the acidic protease specific activity in the 15 day old of red bee shrimp at $\mathrm{pH}$ 2-6 was higher than those of 60-day old shrimp (Table 1). Nevertheless, both shrimp age groups had activity values similar in alkaline conditions. The result on amylase activity demonstrated that the amylase activity was stable over a broad $\mathrm{pH}$ ranging from 4 to 5 , 7 to 8 and 10 to 11 . It showed the maximal activity at $\mathrm{pH} 8(P<0.05)$ in the 60-day old shrimp. Similar to amylase specific activity of the 15-day old shrimp, the optimal $\mathrm{pH}$ for amylase activity was found to be at $\mathrm{pH}$ 8. At optimal condition, the alkaline amylase specific activity was significantly higher than the acidic amylase in both age groups. However, the amylase activity of the 15-day-old shrimp was significantly lower than the older shrimp $(P<0.05)$. On the study of lipase activity, it was examined at various $\mathrm{pH}$ conditions. Lipase in the 60-day old shrimp showed the highest activity at $\mathrm{pH} 12, \mathrm{pH} 10$ and 11 , respectively. In 15-day old shrimp, the lipase activity was significantly lower than the older shrimp $(P<0.05)$. It was stable over a broad range of $\mathrm{pH}$ from 2-12 assay conditions. About cellulase, the study brought out the fact that neutral cellulase had high specific activities $(P<0.05)$.
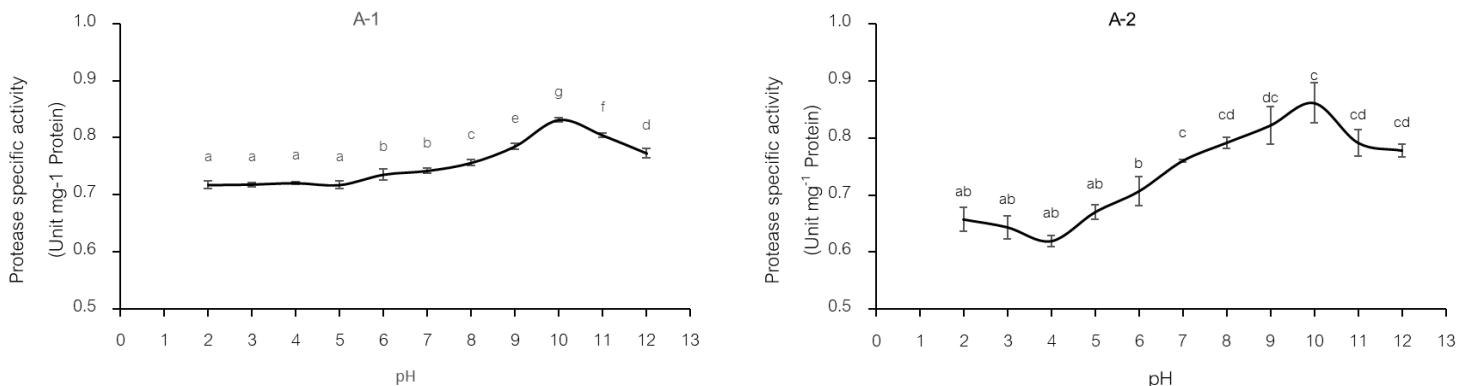

Figure 1: The protease specific activity (A1 and A2).
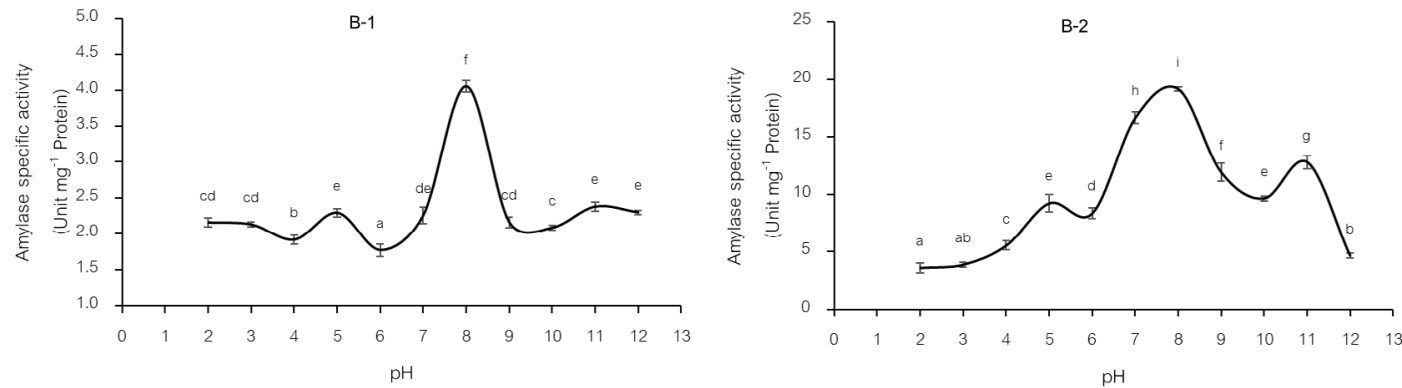

Figure 2: The amylase specific activity (B1 and B2).

\begin{tabular}{|c|c|c|c|c|c|c|}
\hline \multirow{2}{*}{ Raw materials } & \multirow{2}{*}{$\begin{array}{c}\text { Proximate analysis } \\
\text { Protein }(\%)\end{array}$} & \multicolumn{2}{|c|}{ Protein digestibility (\%) } & \multirow{2}{*}{$\begin{array}{c}\text { Proximate analysis } \\
\text { Carbohydrate (\% NFE) }\end{array}$} & \multicolumn{2}{|c|}{ Carbohydrate digestibility (\%) } \\
\hline & & 60 days old & 15 days old & & 60 days old & 15 days old \\
\hline Fish meal & $64.32 \pm 1.42$ & $78.02 \pm 3.79^{\mathrm{ef}}$ & $43.53 \pm 1.30^{f}$ & $15.59 \pm 3.16$ & $80.06 \pm 9.51^{\mathrm{bc}}$ & $57.96 \pm 3.05^{d}$ \\
\hline Soy bean meal & $46.47 \pm 1.38$ & $71.61 \pm 5.92^{\mathrm{e}}$ & $19.11 \pm 2.98^{d}$ & $31.81 \pm 1.44$ & $53.9 \pm 13.09^{a}$ & $22.09 \pm 5.16^{\mathrm{ab}}$ \\
\hline Fermented soy bean & $52.73 \pm 1.17$ & $74.55 \pm 10.71^{\mathrm{e}}$ & $17.34 \pm 1.71^{\mathrm{cd}}$ & $27.47 \pm 2.12$ & $71.47 \pm 7.85^{b}$ & $41.12 \pm 11.60^{c}$ \\
\hline Squid meal & $72.75 \pm 1.33$ & $49.42 \pm 3.23^{d}$ & $16.11 \pm 1.42^{c}$ & $30.66 \pm 2.12$ & $85.49 \pm 7.31^{\mathrm{cd}}$ & $79.62 \pm 5.43^{e}$ \\
\hline Shrimp meal & $40.96 \pm 0.85$ & $50.07 \pm 3.53^{d}$ & $19.26 \pm 0.50^{d}$ & $2.64 \pm 0.91$ & $94.31 \pm 4.05^{d}$ & $50.31 \pm 5.32^{\mathrm{cd}}$ \\
\hline Spirulina & $70.48 \pm 1.35$ & $73.57 \pm 2.27^{e}$ & $19.17 \pm 1.49^{d}$ & $6.54 \pm 1.14$ & $100.00 \pm 5.16^{e}$ & $77.66 \pm 7.75^{\mathrm{e}}$ \\
\hline Rice bran & $19.09 \pm 0.65$ & $39.43 \pm 0.71^{c}$ & $31.98 \pm 2.23^{e}$ & $43.24 \pm 0.72$ & $42.58 \pm 6.45^{\mathrm{a}}$ & $29.71 \pm 0.90^{b}$ \\
\hline Cassava & $1.80 \pm 0.14$ & $24.72 \pm 2.95^{b}$ & $11.72 \pm 0.41^{\mathrm{b}}$ & $69.98 \pm 0.78$ & $85.44 \pm 5.90^{\text {cd }}$ & $58.49 \pm 3.67^{d}$ \\
\hline Wheat flour & $10.55 \pm 0.49$ & $83.09 \pm 5.16^{9}$ & $60.05 \pm 1.18^{g}$ & $79.19 \pm 0.37$ & $92.21 \pm 5.12^{\mathrm{cd}}$ & $75.56 \pm 5.63^{e}$ \\
\hline $\mathrm{Na}$-alginate & $0.00 \pm 0.00$ & $0.00 \pm 0.00^{\mathrm{a}}$ & $0.00 \pm 0.00^{\mathrm{a}}$ & $58.30 \pm 1.08$ & $41.71 \pm 3.62^{\mathrm{a}}$ & $17.87 \pm 1.31^{a}$ \\
\hline Maltodextrin & $0.00 \pm 0.00$ & $0.00 \pm 0.00^{\mathrm{a}}$ & $0.00 \pm 0.00^{\mathrm{a}}$ & $82.57 \pm 0.77$ & $87.09 \pm 1.69^{\mathrm{cd}}$ & $57.58 \pm 3.42^{d}$ \\
\hline$P$-value & & $<0.001$ & $<0.001$ & & $<0.001$ & $<0.001$ \\
\hline
\end{tabular}

Table 1: Protein and carbohydrate digestibility of raw materials by digestive enzyme of red bee shrimp. 


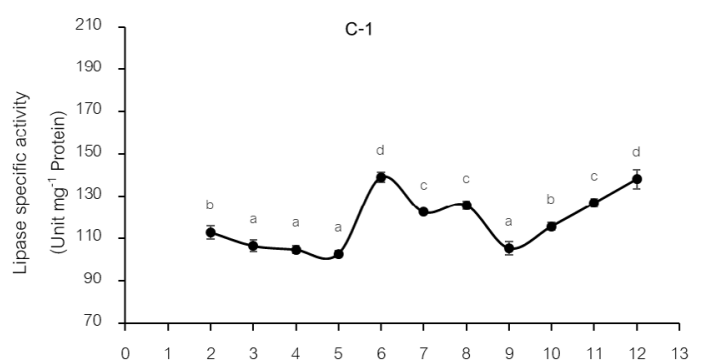

$\mathrm{pH}$

Figure 3: The lipase specific activity (C1 and $\mathrm{C} 2)$.
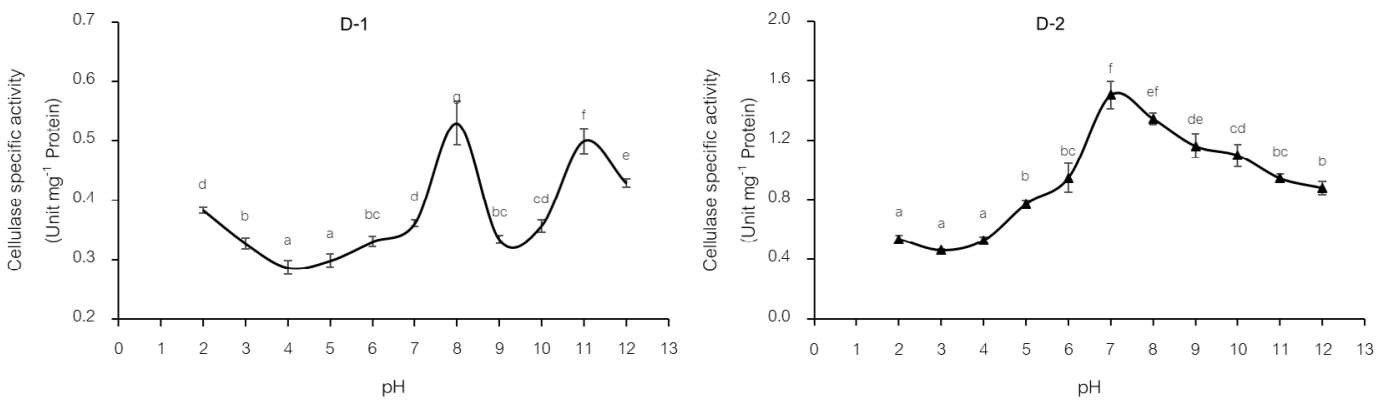

Figure 4: The cellulase specific activity (D1 and D2).
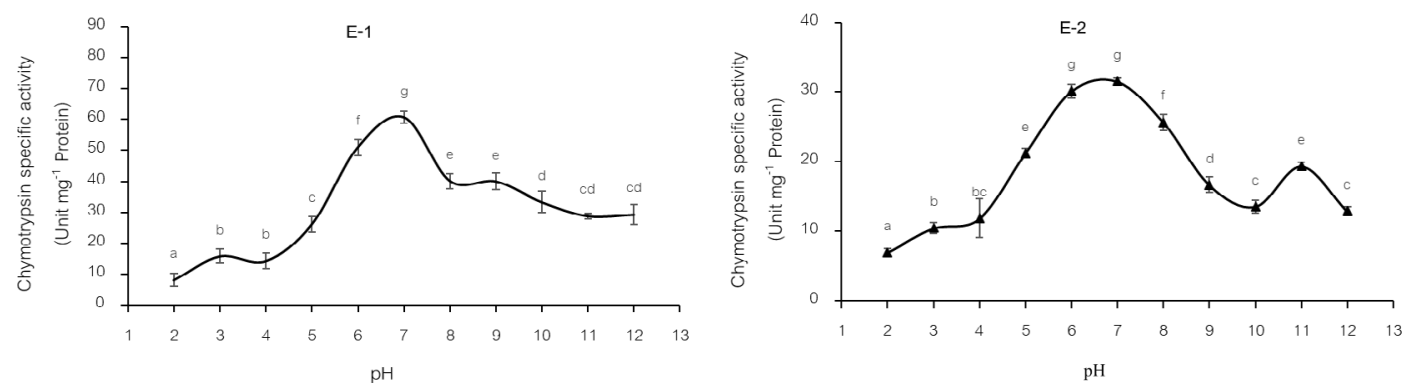

$\mathrm{pH}$

Figure 5: The trypsin specific activity (E1 and E2)
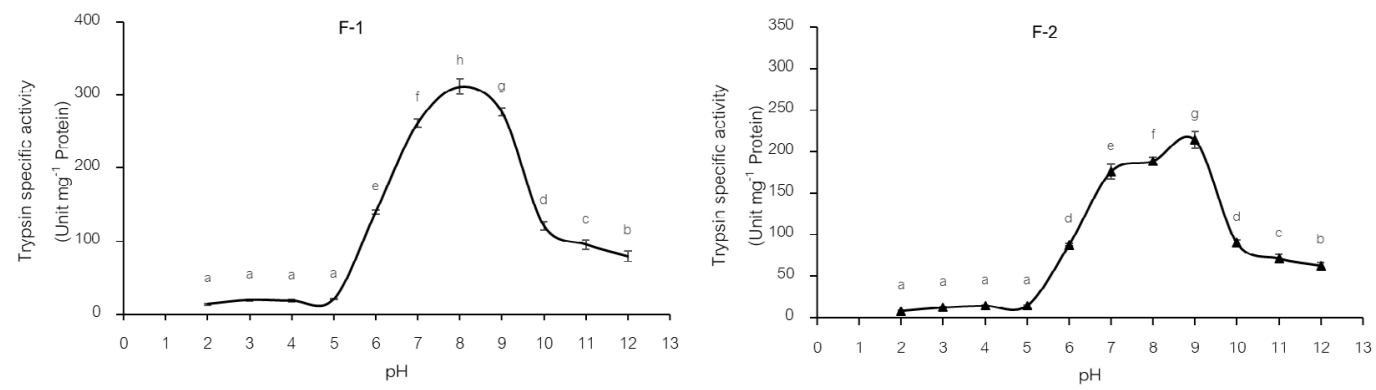

Figure 6: The chymotrypsin specific activity (F1, F2) in the whole-body extracts of 15 (1) and 60 (2) day old of red bee shrimp.

It showed the highest activity at $\mathrm{pH} 7$ assay condition. However, the result revealed that the higher the $\mathrm{pH}$ levels are, the lower the enzyme activity in the 60 -day old shrimp. In the 15 day old shrimp, the cellulase activity was different, as it showed an optimal $\mathrm{pH}$ condition at $\mathrm{pH} 8$ and 11. It is worth noting that the cellulase activity in the 60 day old shrimp was significantly higher than the younger shrimp $(P<0.05)$. When the trypsin activity was analyzed at different $\mathrm{pH}$ values, it was disclosed that the activity at neutral and weak alkaline conditions in both age groups was greater than in acidic condition. In 60-day old shrimp, trypsin activity showed the highest activity at $\mathrm{pH} 8$ assay 
Citation: Kattakdad S, Jintasataporn O, Worawattanamateekul W, Chumkam S (2018) pH Characterization of Digestive Enzyme and In vitro Digestibility of Red Bee Shrimp Caridina cantonensis (Decapoda: Atyidae). J Aquac Res Development 9: 522. doi: 10.4172/2155-9546.1000522

Page 5 of 6

condition. Simultaneously, trypsin activity was stable over a broad $\mathrm{pH}$ ranging from 7 to 9 . It was, nevertheless, observed that at this $\mathrm{pH}$ range, the activity of the 60 -day old shrimp was higher than the 15 -day old shrimp. The study also focused on chymotrypsin activity in both age groups, the chymotrypsin activity in neutral assay condition was higher than in acidic conditions. The chymotrypsin activity showed the highest activity at $\mathrm{pH} 7$ and displayed stability ranging from $\mathrm{pH} 8$ to 12 in alkaline conditions. Yet, the activity of the 15-day old shrimp was significantly lower than the older shrimp $(P<0.05)$ (Figures 3-6).

\section{In vitro digestibility}

The percentage of crude protein and carbohydrate varied among the raw materials (Table 1). Squid meal and spirulina powder contained high crude protein of $72 \%$ and $70 \%$, respectively. Fish meal contained $64 \%$ crude protein. Focusing on the carbohydrate source, maltodextrin and wheat flour contained high carbohydrate of $81.44 \%$ and $79.19 \%$, respectively. According to the study, the results of in vitro raw material digestibility are shown in Table 1 . The total amino acid released after $24 \mathrm{~h}$ of digestion was compared by means of one-way ANOVA. The protein digestibility of enzyme extracted from the 60-day old shrimp was significantly different between raw materials. Fish meal presented the highest protein digestible $(P<0.05)$. It was followed by fermented soy bean, spirulina powder, soy bean meal, shrimp meal and squid meal, respectively. Protein digestion of the 15-day old shrimp showed that fish meal was suitable as a protein source, corresponding to that found in the 60 day old shrimp. It is, nevertheless, observed that protein digestibility of the 60-day old shrimp was higher than the 15-day old shrimp. The carbohydrate digestibility was also studied. It could be seen that there were significant differences between the different raw materials $(P<0.05)$. When compared the carbohydrate digestibility between maltodextrin, wheat flour, cassava, $\mathrm{Na}$-alginate and rice bran in both age, the carbohydrate digestibility of wheat flour, maltodextrin and cassava was found to be more appropriate than rice bran and $\mathrm{Na}$ alginate. However, the older shrimp have more efficient carbohydrate digestion of raw materials than the younger shrimp.

\section{Discussion}

The present investigation produced facts on the specific activity of the main digestive enzymes, namely, protease, amylase, lipase, cellulose, trypsin and chymotrypsin. The progressive change in the digestive tract, the subsequent response to composition and amount of available food affects the development and regulation of the digestive enzymes [8]. From the results, the protease activity of the red bee shrimp under various $\mathrm{pH}$ conditions were significantly different $(P<0.05)$. In the whole shrimp body, the alkaline protease specific activity was significantly higher than acidic isoforms. However, the red bee shrimp differed from atlantic lobster (Homarus americanus) which has an acidic profile [4]. The general $\mathrm{pH}$ properties of digestive proteases from the red bee shrimp is similar to that reported in the Pacific brown shrimp (Penaeus californiensi). The whole digestive tract extract from Pacific brown shrimp shows protease activity through casein testing between pH 6 and 10 which indicates a trend of being slightly less alkaline. This present study is similar to those found in the shrimp Palaemon serratus [36], Penaeus japonicus [12], the lobster Panulirus japonicus [12] and the Pacific crayfish Pleuroncodes planipes [15]. Regarding amylase specific activity, the alkaline amylase specific activity was significantly higher than the acidic amylase. It showed maximal activity at pH 8 in both age groups. This present study is similar to those found in the $F$. subtilis, L. Schmitt and juvenile L. vanamei [7]. This research observed that high protease activity and low amylase activity in the early larvae stage may be caused by digestive enzyme activity closely related to dietary component [18]. Therefore, high protease and amylase activity reflects a diet rich in protein and starch, respectively [17]. Casto et al. [7] reported that commercial diets normally have higher carbohydrate content than the natural diet. Although all shrimp species have the opportunity to develop carnivorous habits in the larvae stage, high starch in commercial diets can induce amylase synthesis and then in the adult stage they also display omnivorous habits. In addition, digestive enzyme's receptiveness to their diets may explain nutritional requirements and thus, physiological adaptation to formulated diets [9]. Under neutral and weak alkaline condition, cellulase activity exhibited high activity. The observation is different to redclaw crayfish Cherax quadricarinatuscrayfish and gecarcinid land crabs as reported by Xue et al. [39], Byrne et al. [6], Figueiredo et al [11]. The researcher suggests that the highest cellulase activity is seen under acid condition. Parallels to the nutrients frequently used in animal diet, the agricultural by-products, vegetables, legumes, and grains are rich in cellulose. The present study showed that the red bee shrimp 15 days after hatching had a cellulase activity lower than the 60-day old shrimp. The increase in the cellulase activity of the 15 days and the 60-day old shrimp relies on the development of gut morphology and the correlation between the shrimp and the microflora that significantly increases in the shrimp's digestive tracts when they grow up. With reference to lipase activity between the shrimp of the different age groups, the results on lipase activity brought about the same result found in juvenile Litopenaeus vanname and spiny lobster larvae $[14,19]$. The significant increase in lipase activity between the 15 and 60-day old shrimp can be explained as the attributing factor in the adaptation of larvae in order to have better digestion and utilization of dietary lipid. Rivera-Perez et al. [31] observed that during the course of metamorphosis gene expression controls lipolytic activity so allows $P$. vannamei larvae external feeding autonomy. The significant increase of enzyme activity in the early larvae stage and grow up stage implies that the larvae have not yet accrued the necessary amount of dietary carbohydrate and lipid for use as an energy source [31] Both trypsin and chymotrypsin in the 15 and 60-day old shrimp were investigated at the same time. The optimum $\mathrm{pH}$ for trypsin activity appeared at the range of 7-9 in both age groups. These results proved to be almost the same with that found in several aquatic animals such as juvenile Litopenaeus vannamei and spiny lobster larvae $[14,19]$. Chymotrypsin activity was highest at $\mathrm{pH}$ 7 in assay condition. The trypsin and chymotrypsin activity of the 60day old shrimp was lower than the 15-day old shrimp. In addition, chymotrypsin activity of shrimp in both age groups was found to be lower than trypsin activity. The high trypsin and chymotrypsin activity in the red bee shrimp larvae in this study indicate that shrimp larvae at the early stage had good protein digestion and then develop another digestive enzyme in the later stage. The adaption of aquatic animals for shifting in diet is the result of the enzyme activity trend [8]. Considering In vitro digestibility, the digestibility of protein and carbohydrate feed materials by red bee shrimp enzyme were investigated. The digestion of fish meal in both age groups had the greatest release of amino acids of all the assay of protein sources. In case of carbohydrate digestibility, wheat flour showed the highest digestive product compared with all the assays of carbohydrate source. The reason that attributed to this result is the digestion efficiency of raw material depends on the chemical composition, material structure and digestive characteristics of each species including assay conditions [5]. The research of Guo et al. [16] found that among aquatic, terrestrial and other animals, fish and shrimp have a lower ability in using carbohydrates as an energy source. However, the 15-day old shrimp had less digestive efficiency and enzyme activity than the 60 days shrimp similar to that found in Macrobrachium rosenbergii [20,21]. This is possibly because of the poorly developed digestive capacity of the larvae $[22,40]$. 
Citation: Kattakdad S, Jintasataporn O, Worawattanamateekul W, Chumkam S (2018) pH Characterization of Digestive Enzyme and In vitro Digestibility of Red Bee Shrimp Caridina cantonensis (Decapoda: Atyidae). J Aquac Res Development 9: 522. doi: 10.4172/2155-9546.1000522

\section{Conclusion}

In conclusion, the results of this study suggest that the larvae of red bee shrimp has enzymatic activity less than the older shrimp, however, this does not include protease. The larvae of red bee shrimp have an ability to use a protein source and are considered as carnivorous feeding behaviour. Furthermore, red bee shrimps has diet digestibility in neutral to mid alkaline conditions. The animal protein materials are appropriate for red bee shrimp feed ingredients with low fiber and carbohydrate. Fish meal is appropriate to be a protein source and wheat flour is the best choice of carbohydrate source in red bee shrimp feed.

\section{References}

1. Areekijseree $M$, Engkagul $A$, Kovitvadhi $U$, Thongpan $A$, Mingmuang $M$, et al. (2004) Temperature and $\mathrm{pH}$ characteristics of amylase and proteinase of adult freshwater pearl mussel, Hyriopsis (Hyriopsis) bialatus Simpson 1900. Aquaculture 234: 575-587.

2. Bernfeld P (1955) Enzymes of carbohydrate metabolism. In: Colowick, S.P., Kaplan, N.O. (Eds.) Method in Enzymol 1. Academic Press, New York, USA.

3. Bezerra RS, Lins EJF, Alencar RB, Paiva PMG, Chaves MEC, et al. (2005) Alkaline proteinase from intestine of Nile tilapia (Oreochromis niloticus). Process Biochem 40: 1829-1834.

4. Biesiot PM, MacDowell-Capuzzo J (1990) Digestive protease, lipase and amylase activities in stage I larvae of the American lobster Homarus americanus. Comp. Bioehem. Physiol 95: 47-54.

5. Brunson JF, Romaire RP, Reigh RC (1997) Apparent digestibility of selected ingredients in diets for white shrimp Penaeus setiferus L. Aquac. Nutr 3: 9-16.

6. Byrne KA, Lehnert SA, Johnson SE, Moore SS (1999) Isolation of a cDNA encoding a putative cellulase in the red claw crayfish Cherax quadricarinatus. Gene 239: 317-324.

7. Castro PF, Freitas ACV, Santana WM, Costa HMS, Carvalho LB (2012) Comparative study of amylases from the midgut gland of three species of Penaeid shrimp. J Crustacean Biol 32: 607-613.

8. Chakrabarti R, Rathore RM, Mittal P, Kumar S (2000) Functional changes in digestive enzyme and characterization of proteases of silver carp and bighead carp hybrid, during early ontogeny. Aquaculture 253: 694-702.

9. Coccia E, Varricchio E, Paolucci M (2011) Digestive enzymes in the crayfish Cherax albidus: Polymorphism and partial characterization. Int $\mathrm{J}$ Zool.

10. El-Beltagy AE, El-Adawy TA, Rahma EH, El-Bedawey AA (2004) Purification and characterization of an acidic protease from the viscera of bolti fish (Tilapia nilotica). Food Chem 86: 33-39.

11. Figueiredo MSRB, Kricker JA, Anderson AJ (2001) Digestive enzyme activity in the alimentary tract of redclaw crayfish, Cherex quadricarinatus (Decapoda: Parastacidea). J Crustacean Biol 21: 334-344.

12. Galgani F, Nagayama F (1987) Digestive proteinases in the japanese spiny lobster Panulirus japonieus. Comp Biochem Physiol 87B: 889-893.

13. Galgani F, Benyamin Y (1985) Radiommunoassay of shrimp trypsin: Application to the larval development of Penaeus japonicus Bate, 1888. J Exp Marine Biol Ecol 87: 145-151.

14. Gamboa-Delgado J, Molina-Poveda C, Cahu C (2003) Digestive enzyme activity and food ingesta in juvenile shrimp Litopenaeus vannamei (Boone, 1931 ) as a function of body weight. Aquaculture Res 34: 1403-1411.

15. Garcia-Carreno FL (1992) The digestive protease of langostilla (Pleuroncodes palanipes, Decapoda): their partial characterization and the effect of food on their composition. Comp. Biochem Physiol 103B: 575-578.

16. Guo R, Liu YJ, Tian LX, Huang JW (2006) Effect of dietary cornstarch levels on growth performance, digestibility and microscope structure in the white shrimp, Litopenaeus vannamei reared in brackish water. Aquac Nutr 12: 83-88.

17. Johnston DJ (2003) Ontogenetic changes in digestive enzymology of the spiny lobster, Jasus edwardsii Hutton (Decapoda, Palinuridae). Marine Biology 143: 1071-1082.

18. Johnston DJ, Freeman J (2005) Dietary preference and digestive enzyme activities as indicators of trophic resource utilization by six species of crab. Biological Bulletin 208: 36-46.
19. Johnston DJ, Ritar AJ, Thomas CW (2004) Digestive enzyme profiles revea digestive capacity and potential energy sources in fed and starved spiny lobster (Jasus edwardsii) phyllosoma larvae. Comparative Biochem Physiol 138: 137 144

20. Jun-Jie Y, Yun-Long Z, Qun W, Zhong-Ling Z, Xian-Cheng H, et al. (2006) Biochemical compositions and digestive enzyme activities during the embryonic development of prawn, Macrobrachium rosenbergii. Aquaculture 253: 573-582.

21. Kamarudin SM, Jones AD, Vay L, Abidin AZ (1994) Ontogenetic change in digestive enzyme activity during larval development of Macrobrachium rosenbergii. Aquaculture 123: 323-333.

22. Kolkovski S (2001) Digestive enzymes in fish larvae and juvenile simplications and applications to formulated diets Aquaculture 200: 181-201.

23. Lai H, Shy J (2009) The larval development of Caridina pseudodenticulata (Crustacea: Decapoda: Atyidae) reared in the laboratory with a discussion of larval metamorphosis types. The Raffles Bulletin Zool 20: 97-107.

24. Lowry HO, Rosebrough JN, Farr AL, Randall RJ (1951) Protein measurements with the Folin phenol reagent. J. Biol. Chem 193: 265-275.

25. Markweg H, Lang MS, Wagner F (1995) Dodecanoic acid inhibition of lipase from Acinetobacter sp. OPA 55. Enzyme Microbial Technol 17: 512-516.

26. Miller GL (1959) Use of dinitrosalicylic acid reagent for determination of reducing sugar. Analytical Chem 31: 426-428.

27. Nankervis L, Southgate PC (2009) Enzyme and acid treatment of fish meal for incorporation into formulated microbound diets for barramundi (Lates calcarifer) larvae. Aquaculture nutrition 15: 135-143.

28. Natalia Y, Hashim R, Ali A, Chong A (2004) Characterization of digestive enzymes in a canivoous ornamental fish, the Asian bony tongue Scleropages formosus (Osteoglossidae). Aquaculture 233: 305-320

29. Pan Lu Q, Xiao S, Guo Q, Zhang P, Hong X, et al. (2005) Effects of different dietary protein content on growth and protease activity of Eriocheir sinensis larvae. Aquaculture 246: 313-319.

30. Perera E, Moyano FJ, Rodriguez-Viera L, Cervantes A (2010) In vitro digestion of protein sources by crude enzyme extracts of the spiny lobster Panulirus argus (Latreille, 1804) hepatopancreas with different trypsin isoenzyme patterns. Aquaculture 310: 178-185.

31. Rivera-Perez C, Toro AN, Garcia-Carreno F (2010) Digestive lipase activity through development and after fasting and re-feeding in the white leg shrimp Penaeus vannamei. Aquaculture 300: 163-168.

32. Rungruangsak-Torrissen K, Rustad A, Sunde J, Eiane SA, Jensen HB (2002) In vitro digestibility based on fish crude enzyme extract for prediction of feed quality in growth trials. J Sci Food Agric 82: 644-654.

33. Sunde J, Taranger GL, Rungruangsak TK (2001) Digestive protease activities and free amino acids in white muscle as indicators for feed conversion efficiency and growth rate in Atlantic salmon (Salmo salar L). Fish Physiol Biochem 25: 335-345.

34. Stauffer C (1989) Effect of pH on activity. Enzyme assay for food scientists. Van Nostrand Reinholdy/ AVI, New York, USA.

35. Torrissen KR, Lied E, Espe M (1994) Differnces in digestion and absorption of dietary protein in Atlantic salmon (Salmo Salar) with genetically different trypsin isozymes. J. Fish Biol 45: 1087-1104.

36. Van Wormhoudt A, Ceccaldi HJ, Martin BJ (1980) Adaptation de la teneur en enzymes digestives de l'hepatopancreas de Palaemon serratus (Crustacea, Decapoda) a la composition d'aliments experimentaux. Aquaculture 21: 63-78.

37. Vega-Villasante F, Nolasco H, Civera R (1995) The digestive enzymes of the Pacific brown shrimp Penaeus californiensis II. Properties of protease activity in the whole digestive tract. Comp Biochem. Physiol I 12: 123-129.

38. Xiao X, Han D, Zhu X, Yang Y, Xie S, et al. (2014) Effect of dietary cornstarch levels on growth performance, enzyme activity and hepatopancreas histology of juvenile red swamp crayfish, Procambarus clarkia (Girard). Aquculture 426: 112-119.

39. Xue XM, Anderson AJ, Richardson NA, Anderson AJ, Xue GP, et al. (1999) Characterization of cellulase activity in the digestive system of the redclaw crayfi sh (Cherax quadricarinatus). Aquaculture 180: 373-386.

40. Yam RSW, Dudgeon D (2005) Genetic differentiation of Caridina cantonensis (Decapoda: Atyidae) in Hong Kong streams. J North American Benthol Society 24: 845-857. 